\title{
Investigating University Students' Views on Distance Education at Associate Degree Level
}

\author{
Recep ÖZ ${ }^{1}$ \\ ${ }^{1}$ Department of Computer Education and Instructional Technology, Faculty of Education, Erzincan Binali \\ Yildirim University, Erzincan, Turkey \\ Correspondence: Recep ÖZ, Department of Computer Education and Instructional Technology, Faculty of \\ Education, Erzincan Binali Yildirim University, Erzincan, Turkey. E-mail: recepoz@erzincan.edu.tr
}

Received: March 26, 2021

doi:10.5539/ies.v14n8p67
Accepted: May 1, $2021 \quad$ Online Published: July 27, 2021

URL: https://doi.org/10.5539/ies.v14n8p67

\begin{abstract}
The study aimed to determine the associate degree students' views on the dimensions of personal suitability, effectiveness, teaching, and predisposition towards teaching offered in distance education environments and examine whether their views differed significantly according to gender, class, and vocational school type.

The data of the study were collected from 2061 students studying in vocational schools of a state university located in eastern Turkey. All students in the study population were aimed to be reached; however, 2061 out of 2963 students who participated voluntarily and answered all the questions were included. Among these 2061 students, 1152 were male and 909 were female. When classified according to school type, 1429 participants were studying at vocational schools, 401 at health, 136 at justice, and 95 were studying at tourism. Learners' Views on Distance Education Scale (LVoDE) was used as the data collection tool. LVODE included 18 items and four factors as personal appropriateness, effectiveness, informativeness and predisposition. The scale was on 5-point Likert rating scale ranging from 1 to 5 indicating 1 (never agree), 2 (rarely agree), 3 (sometimes agree), 4 (usually agree), 5 (always agree). The reliability coefficients of the scale including four sub-dimensions as personal suitability, effectiveness, teaching, and predisposition varied between .81 and .91 . The descriptive statistics were used to ascertain the opinions on the sub-dimensions of personal appropriateness, effectiveness, informativeness and predisposition offered to students in distance education environments. A factorial ANOVA test was performed for independent samples to check whether students' views on teaching offered in distance education settings differed significantly according to gender, grade level, and type of school. According to the research results, it was noticed that the students did not find themselves sufficient for distance education activities in terms of personal convenience and effectiveness and thought that face-to-face education was more effective than distance education. They regarded themselves insufficient in completing their homework and similar tasks given during their online classes by teachers. There was no significant difference in views of the students upon distance education in terms of both gender and grade levels. However, a significant difference was found in their views on distance education according to the types of vocational schools. The opinions of the students studying in health and justice vocational schools were found to be at a more positive level than the ones enrolled in hotel and tourism vocational schools.
\end{abstract}

Keywords: distance education, face to face classes, associate degree students, vocational school

\section{Introduction}

The improvements in information and communication technologies have contributed upon the development of models that are an alternative to the traditional educational model. One of these alternatives is distance education. According to Yalın (2001), distance education is defined as a system in which teachers and students who are physically located in separate places interact via technology. İşman (2008) defines distance education as a model of an education system where teachers and students are not required to be in the same places and educational activities are implemented via postal services and information communication technologies. With the emergence of the COVID-19 pandemic in China in late 2019 and its spread to the world in 2020, the distance education model has been put into practice both in Turkey and in many developed and developing countries (Eken, Tosun, \& Tuzcu Eken, 2020). Developments in communication technologies and the level that regional and global communication networks have reached support distance education practices much better than in previous periods, and the distance education model has been administered at different levels of education, from primary education to higher 
education (Eken, Tosun, \& Tuzcu Eken, 2020).

Distance education is regarded as an alternative model to face-to-face education (Başar, Arslan, Günsel, \& Akpinar, 2019). It is also possible to be mentioned as reinforcing this especially with the COVID-19 outbreak. Some researchers have stated that distance education is not as effective as face-to-face education; and therefore, it should not be considered as an alternative to face-to-face education (Yılmaz \& Düğenci, 2010). For example, İşman (2008), and Özkul and Girginer (2001) consider distance education as an educational model. Kaya (2002), on the other hand, regards distance education as a form of instruction instead of an alternative alongside face-to-face education.

As with other instructional models, some conditions that are necessary for the implementation of the distance learning model are required to be established. However, it is clear that distance education has some different requirements than face-to-face formal education (Bilgic \& Tüzün, 2015). In addition to the infrastructure eligibility that distance education necessitates, it is also important for teachers and students to be ready for this process in order for distance education model to be successful. Moreover, educational, social, technical and administrative supports are remarkable in addition to student support services in open and distance education practices (Durak, 2017a). Failure to provide these supports, practices performed by incomplete and inadequate infrastructures and teachers can lead to students' developing negative attitudes towards open and distance education.

In some studies, it has been found that there are some problems related to distance education practices. Web-based distance education practices administered in higher education create different problems for lecturers and for students (Bilgiç \& Tüzün, 2015). A study on the problems encountered by campus students in simultaneous distance education (Kurmac1 \& Acar, 2018) has found that there are problems in three different areas as communication, education and system. Another study (Falowo, 2007) states that, in web-based distance education, there may be obstacles arising from institutional reasons as well as problems related to students and lecturers. According to Hara and King (1999), students' not considering what they expect from distance education courses or distance education programs is also one of the most important obstacles in web-based distance education. Inappropriate guidelines, lack of feedback, and technology problems are also cited as reasons for failing to meet student expectations. In a study that addresses the problems experienced in distance education during the Covid-19 pandemic period (Kurtüncü \& Kurt, 2020), students affirm that there are problems such as lack of distance education infrastructure, limitation of accessing distance education and exam anxiety. In another study (Wang, Cheng, Yue, \& McAleer, 2020), it is specified that impossibilities in Internet access have been among the most problematic issues for students. In addition to technical problems, problems with insufficient interaction and inability to motivate in the teaching process have been expressed (Birişçi, 2013). During distance education, students experience a feeling of isolation and, as result, loss of motivation is regarded as an important problem (Durak, 2017b). In a previous study (Erzen \& Ceylan, 2020), it has been stated that the lecturer's ability of making effective presentations, communicating quickly and creating qualified content in distance learning process have been evaluated positively. On the contrary, it has been found that the faculty who are content with sharing notes only, share unqualified content, do not communicate and give incomprehensible instructions in their assignments are evaluated negatively. It has also been noted that distance education is not suitable for practical courses and is perceived as a problem by students (Wang et al., 2020). According to Durak (2017a), students may experience a sense of isolation as well as guidance, lack of management and some possible motivation losses unless open and distance learning institutions provide quality support services. In a study in which distance education practice is evaluated according to the perspective of students (Özyürek, Begde, Yavuz, \& Özkan, 2016), it is reported that internet connection interruption has prevented course follow-up. In the same study, it is specified that the instructional methods used, and the problems experienced during the exam have been perceived by the students as important problems. A study (Erzen \& Ceylan, 2020) has found that some students' not having access to computers or the Internet, and inadequacy of the devices accessed is a cause of concern for students. In a study analyzing the compliance of vocational school instructors in distance education process (Öztürk, 2020), it has been found that the urgent transition to distance education process creates problems for some unprepared faculty members. In another study (Ibicioglu \& Antalya, 2005), it has been observed that motivation and perception of distance education are important for the success of distance education.

Some problems are encountered in the design and implementation phases of Internet-based education. There are also various concerns regarding the recognition, quality, student, teacher and corporate identity of online education. Can (2020) has emphasized that not only quantity but quality is important in open and distance education. According to Can (2020), the open and distance education system in Turkey is required to be strengthened in terms of infrastructure, access, security, content, design, implementation, quality, legislation and 
pedagogy.

The aim of the research is to evaluate the views of associate degree students participating in distance education towards the teaching offered in distance education environments. For this purpose, answers to the following questions have been sought:

1) Is there a significant difference between the views of students on personal appropriateness, effectiveness, informativeness and predisposition in terms of gender?

2) Is there a significant difference between the views of students on personal appropriateness, effectiveness, informativeness and predisposition in terms of level of grade?

3) Is there a significant difference between the views of students on personal appropriateness, effectiveness, informativeness and predisposition in terms of school type?

\section{Method}

\subsection{Research Group}

The data were collected from the students studying at vocational schools of a state university in eastern Turkey. All students in the study population were aimed to be reached; however, 2061 out of 2963 students who participated voluntarily and answered all the questions were included. Among these 2061 students, 1152 were male and 909 were female. When classified according to school type, 1429 participants were studying at vocational schools, 401 at health, 136 at justice, and 95 were studying at tourism.

The students in the research group included associate degree students studying at vocational schools of a state university in the Eastern Anatolian region of Turkey. The students who did not want to participate as well as students who participated but did not answer some of the questions were excluded from the study.

Table 1. Distribution of students participating into the study according to school type and gender

\begin{tabular}{lcl}
\hline Variable & Frequency & Percent \\
\hline Gender & & \\
\hline Male & 1152 & 55.9 \\
Female & 909 & 44.1 \\
\hline Total number of students & 2061 & 100.0 \\
\hline School Type & & \\
\hline Vocational Schools & 1429 & 69.3 \\
Health Group & 401 & 19.5 \\
Justice Group & 136 & 6.6 \\
Tourism Group & 95 & 4.6 \\
\hline Total number of students & 2061 & 100.0 \\
\hline Grade Level & & \\
\hline Grade One & 1542 & 74.8 \\
Grade Two & 519 & 25.2 \\
\hline Total number of students & 2061 & 100.0 \\
\hline
\end{tabular}

The distribution of the students participating into the study according to gender, school type and grade level was presented in Table 1. The study included 1429 students from the Vocational School group, 401 from the Vocational School of Health Services group, 136 from the Vocational School of Justice group, and 95 from the Vocational School of Tourism and Hotel Management group. $55.9 \%$ of the students who participated were male and $44.1 \%$ were female. According to the grade level, $74.8 \%$ of the participating students were studying at grade one and $25.2 \%$ were studying at grade two.

\subsection{Research Instrument}

Student Views on Distance Education (LVODE) scale developed by Yıldırım, Yıldırım, Çelik and Karaman (2014) was used as the data collection tool. LVODE included 18 items and four subdimensions as personal appropriateness, effectiveness, informativeness and predisposition. The scale was on 5-point Likert rating scale ranging from 1 to 5 indicating 1 (never agree), 2 (rarely agree), 3 (sometimes agree), 4 (usually agree), 5 (always agree). 
Table 2. Reliability coefficients of learner views on distance education scale

\begin{tabular}{cccc}
\hline Dimensions & Items & $\begin{array}{c}\text { Original Scale } \\
\mathrm{N}=1040 \\
\text { Cronbach's Alpha }\end{array}$ & $\begin{array}{c}\text { Current Practice } \\
\mathrm{N}=2061 \\
\text { Cronbach's Alpha }\end{array}$ \\
\hline Personal Appropriateness & $1-6(6)$ & .862 & .886 \\
Effectiveness & $7-11(5)$ & .818 & .910 \\
Informativeness & $12-15(4)$ & .807 & .862 \\
Predisposition & $16-18(3)$ & .799 & .805 \\
Total & 18 & .864 & .859 \\
\hline
\end{tabular}

The reliability coefficients for the original scale and factors and the reliability coefficients for the scale and factors obtained in this study were presented in Table 2 . The calculated internal consistency coefficients indicated that the reliability coefficients calculated for the original were similar to the current practice, and the results obtained from the current practice were possible to be used for answering the research questions.

In the "Personal Appropriateness" dimension, there were six questions about the extent to which the student considered themselves appropriate for distance education. The internal consistency coefficient calculated in the current study on this dimension was .89. There were five questions in the "effectiveness" sub-dimension. In this dimension, there were questions that included the students' views on how appropriate the teaching process was for the preparation of learning, the learning process and the realization of learning. The internal consistency coefficient calculated in the current study for this dimension was .91. The internal coefficient of consistency calculated in the current study regarding the third subdivision of "Informativeness" was .86. In this dimension, distance education and traditional educational practices were compared in terms of instructional processes. Receiving a high score from this dimension could be interpreted as students' regarding traditional education more effective in instructional process rather than distance education. Finally, in the "Predisposition" dimension, questions about the extent to which the student was prone to completing the given tasks were included. The internal coefficient of consistency calculated in the current study related to this dimension was .86 .

\subsection{Statistical Analysis}

Descriptive statistics were used to ascertain the opinions on the sub-dimensions of personal appropriateness, effectiveness, informativeness and predisposition offered to students in distance education environments. A factorial ANOVA test was performed for independent samples to check whether students' views on teaching offered in distance education settings differed significantly according to gender, grade level, and type of school. As Field (2009) pointed out, the Factorial ANOVA test based on two or more independent variables analyzed whether there was a significant difference between the averages of two or more groups.

\section{Findings}

The scores of students for LVODE and its sub-dimensions were presented in Table 3. According to the answers of totally 2061 associate degree students, it was understood that the mean scale score was 48.36 . According to this finding, students' views on distance education could be said to be at a moderate level.

Table 3. Results for LVODE and its sub-dimension scores of students

\begin{tabular}{ccccccc}
\hline Dimensions & N & Min. & Max. & Mean & Std. Deviation & $\begin{array}{c}\text { Percentage } \\
\text { Score }\end{array}$ \\
\hline Personal Appropriateness & 2061 & 6.00 & 30.00 & 15.87 & 7.16 & 41.13 \\
Effectiveness & 2061 & 5.00 & 25.00 & 11.35 & 5.83 & 31.75 \\
Informativeness & 2061 & 4.00 & 20.00 & 15.00 & 4.86 & 68.75 \\
Predisposition & 2061 & 3.00 & 15.00 & 6.14 & 3.28 & 26.17 \\
Total & 2061 & 18.00 & 90.00 & 48.36 & 13.80 & 42.17 \\
\hline
\end{tabular}

When the scores from each dimension of the scale were converted to the hundred-point system (Percentage Score= the average score of the sub-dimension according to the zero-starting point/the highest score that can be obtained according to the zero-starting point in this dimension) $\mathrm{x} 100$ ), it was noticed that the sub-dimension and total score averages were low. Although the score in the informativeness dimension appeared to be above average, this high score indicated the negativity of the view towards distance education. Because there was a comparison between the 
traditional model and distance education model in this dimension, the high score indicated that traditional education was more effective than distance education.

The average score of the students in the personal appropriateness dimension was 15.87. Considering that the lowest score possible to be obtained was 6 and the highest score was 30, it could be said that this average was at a moderate level. In other words, students considered themselves moderately appropriate for distance education activities.

It was observed that the average for effectiveness dimension was closer to the lower limit (11.25), and therefore at a low level. The average for the informativeness dimension was found to be 14.00. It could be mentioned that students did not find distance education very suitable for preparation to learning, learning process and realization of learning.

It was understood that the average score for the informativeness dimension (15.00) was above the mid-level and good because it was between the intermediate level and the upper limit. For this reason, it could be said that students considered traditional education more effective than distance education in the instructional process.

It could be said that the score for the predisposition dimension was close to the lower limit of 3 (6.14); therefore, the score for the predisposition dimension was low. It was understood that the students considered themselves inadequate to complete the assignments and similar tasks assigned to them.

Table 4. Descriptive statistics according to gender, grade level, and school type

\begin{tabular}{|c|c|c|c|c|c|}
\hline Gender & Grade Level & School Type & Mean & Std. Deviation & $\mathrm{N}$ \\
\hline \multirow{15}{*}{ Male } & \multirow{5}{*}{ Grade One } & Vocational Schools & 49.07 & 14.00 & 655 \\
\hline & & Health Group & 52.84 & 12.23 & 143 \\
\hline & & Justice Group & 52.17 & 14.80 & 58 \\
\hline & & Tourism Group & 47.44 & 16.23 & 41 \\
\hline & & Total & 49.80 & 13.96 & 897 \\
\hline & \multirow{5}{*}{ Grade Two } & Vocational Schools & 45.69 & 15.84 & 210 \\
\hline & & Health Group & 53.10 & 13.19 & 20 \\
\hline & & Justice Group & 52.00 & 14.87 & 13 \\
\hline & & Tourism Group & 43.67 & 9.63 & 12 \\
\hline & & Total & 46.50 & 15.49 & 255 \\
\hline & \multirow{5}{*}{ Total } & Vocational Schools & 48.25 & 14.53 & 865 \\
\hline & & Health Group & 52.87 & 12.31 & 163 \\
\hline & & Justice Group & 52.14 & 14.70 & 71 \\
\hline & & Tourism Group & 46.58 & 15.00 & 53 \\
\hline & & Total & 49.07 & 14.37 & 1152 \\
\hline \multirow{15}{*}{ Female } & \multirow{5}{*}{ Grade One } & Vocational Schools & 49.30 & 13.51 & 399 \\
\hline & & Health Group & 48.26 & 12.35 & 172 \\
\hline & & Justice Group & 52.62 & 13.49 & 45 \\
\hline & & Tourism Group & 44.45 & 10.33 & 29 \\
\hline & & Total & 49.04 & 13.13 & 645 \\
\hline & \multirow{5}{*}{ Grade Two } & Vocational Schools & 41.58 & 11.03 & 165 \\
\hline & & Health Group & 45.95 & 12.11 & 66 \\
\hline & & Justice Group & 52.55 & 13.71 & 20 \\
\hline & & Tourism Group & 43.69 & 9.52 & 13 \\
\hline & & Total & 43.61 & 11.83 & 264 \\
\hline & \multirow{5}{*}{ Total } & Vocational Schools & 47.04 & 13.30 & 564 \\
\hline & & Health Group & 47.62 & 12.31 & 238 \\
\hline & & Justice Group & 52.60 & 13.45 & 65 \\
\hline & & Tourism Group & 44.21 & 9.97 & 42 \\
\hline & & Total & 47.46 & 12.99 & 909 \\
\hline \multirow{3}{*}{ Total } & \multirow{3}{*}{ Grade One } & Vocational Schools & 49.16 & 13.81 & 1054 \\
\hline & & Health Group & 50.34 & 12.49 & 315 \\
\hline & & Justice Group & 52.37 & 14.18 & 103 \\
\hline
\end{tabular}




\begin{tabular}{lllll} 
& Tourism Group & 46.20 & 14.08 & 70 \\
& Total & 49.48 & 13.62 & 1542 \\
\hline \multirow{4}{*}{ Grade Two } & Vocational Schools & 43.88 & 14.06 & 375 \\
& Health Group & 47.62 & 12.66 & 86 \\
& Justice Group & 52.33 & 13.95 & 33 \\
& Tourism Group & 43.68 & 9.37 & 25 \\
& Total & 45.03 & 13.81 & 519 \\
\hline \multirow{5}{*}{ Total } & Vocational Schools & 47.77 & 14.06 & 1429 \\
& Health Group & 49.75 & 12.56 & 401 \\
& Justice Group & 52.36 & 14.07 & 136 \\
& Tourism Group & 45.54 & 13.01 & 95 \\
& Total & 48.36 & 13.80 & 2061 \\
\hline
\end{tabular}

The descriptive statistics according to gender, grade level and school type were presented in Table 4 . The students were grouped under male and female according to gender, first and second grade according to grade level, and four subgroups according to school type. These subgroups were vocational school, health (health services vocational school) group, justice (justice vocational school) group and tourism (hotel management and tourism vocational school) groups.

Table 5. Factorial ANOVA test results for independent groups regarding students' views on teaching offered in distance education environments according to gender, grade level and school type

\begin{tabular}{ccccccc}
\hline Source & $\begin{array}{c}\text { Type III Sum of } \\
\text { Squares }\end{array}$ & df & $\begin{array}{c}\text { Mean } \\
\text { Square }\end{array}$ & F & p & $\eta^{2}$ \\
\hline Corrected Model & $16690.658^{\mathrm{a}}$ & 15 & 1112.711 & 6.057 & .000 & .043 \\
Intercept & 1253669.548 & 1 & 1253669.548 & 6824.019 & .000 & .769 \\
Gender & 646.327 & 1 & 646.327 & 3.518 & .061 & .002 \\
Grade & 671.553 & 1 & 671.553 & 3.655 & .056 & .002 \\
School type & 5275.187 & 3 & 1758.396 & 9.571 & .000 & .014 \\
Gender*Grade & 29.969 & 1 & 29.969 & .163 & .686 & .000 \\
Gender*School type & 886.529 & 3 & 295.510 & 1.609 & .185 & .002 \\
Grade*School type & 1468.220 & 3 & 489.407 & 2.664 & .046 & .004 \\
Gender* Grade* School type & 330.025 & 3 & 110.008 & .599 & .616 & .001 \\
Error & 375695.646 & 2045 & 183.714 & & & \\
Total & 5212236.000 & 2061 & & & &
\end{tabular}

a. R Squared $=.043$ (Adjusted R Squared $=.036$ ).

Factorial ANOVA test results in independent groups to answer the second research question were presented in Table 5. Whereas the results of the analysis revealed that student views on teaching offered in distance education settings differed depending on the type of school $\left(\mathrm{F}_{(3-2045)}=9.571, \mathrm{p}<.01, \eta^{2}=.014\right)$, it was observed that there were no significant differences according to gender $\left(\mathrm{F}_{(1-2045)}=3.518, \mathrm{p}>.05\right)$ and grade level $\left(\mathrm{F}_{(1-2045)}=3.655, \mathrm{p}>.05\right)$. Approximately $3.6 \%$ of the students' views on education offered in distance education environments were explained according to the type of school. It was found that the average scores of students in the Health $(\bar{X}=49.75$, $\mathrm{Ss}=12.56)$ and Justice $(\bar{X}=52.36, \mathrm{Ss}=14.07)$ groups were significantly higher than the average scores of students in the Vocational School $(\bar{X}=47.77, \mathrm{Ss}=14.06)$ and Tourism $(\bar{X}=45.54, \mathrm{Ss}=13.01)$ group $(\mathrm{p}<.05)$. On the other hand, it was understood that the effect of the school type on the views of the education offered in distance education environments was low.

The null hypothesis was accepted that the joint interaction of gender*grade level, gender*school type and gender*class*school type had no effect upon students' views on teaching in distance education environments. It was found that gender and grade level together had no effect on the views of students towards teaching in distance education environments $\left(\mathrm{F}_{(1-2045)}=9.571, \mathrm{p}>.05\right)$. Similarly, it was understood that gender and school type together had no effect upon the views of students towards teaching in distance education environments $\left(\mathrm{F}_{(3-2045)}=1.609\right.$, p>.05). In addition, gender, grade level and school type together were observed to have no effect upon the views of 
students towards teaching in distance education environments $\left(\mathrm{F}_{(3-2045)}=.599, \mathrm{p}>.05\right)$. On the other hand, it was specified that grade level and type of school affected students' views on teaching offered in distance education environments $\left(\mathrm{F}_{(3-2045)}=9.571, \mathrm{p}<.05, \eta^{2}=.004\right)$. It was understood that the effect was at a very low level. The alternative hypothesis was accepted that the joint interaction of class level and school type together affected students' views on teaching offered in distance education environments.

\section{Results, Discussion and Further Research}

Students' scores in the personal appropriateness dimension were at a moderate level. This level indicated that students did not consider themselves sufficiently appropriate for distance education activities (moderate).

It was understood that the averages of the students' views related to the effectiveness dimension were low. As part of the preparation for learning, learning process and realization of learning, it was understood that the level of students for considering themselves appropriate for the distance education model remained at a low level.

The average scores in relation to the informativeness dimension could be interpreted as that students generally found traditional education more effective than distance education in the instructional process.

The average score of students for the dimension of predisposition was also close to the lower limit level. This finding could be interpreted as students' considering themselves inadequate in completing assignments and similar tasks assigned to them.

Students' inadequate views on teaching offered in distance education environments were possible to be affected by infrastructure and process issues. For instance, students' not having sufficient knowledge of distance learning processes, not having the ability of using the process effectively, the content offered by instructors' not being attractive enough for students and students' not having the tools, environments and equipment necessary to access distance learning could be considered in this context.

In some studies, it was found that deficiencies related to faculty members, infrastructure and students negatively affected the distance education process. In distance education, it was stated that there could be deficiencies arising from institutional reasons as well as problems caused by students and lecturers (Falowo, 2007). It was stated that the failure of students to find what they hoped in distance education process was also a significant obstacle in the distance education process (Hara \& King, 1999). In addition, issues such as lack of infrastructure, limited access to distance education and exam anxiety were identified as important problems related to distance education process (Kürtüncü \& Kurt, 2020). Problems such as internet access (Wang, Cheng, Yue, \& McAleer, 2020), technical problems, lack of interaction and lack of motivation (Biriş̧̧i, 2013), internet connection outage (Özyurek, Begde, Yavuz, \& Özkan, 2016), device inadequacy, lack of computer or internet connection of some students, the inability of instructors to make effective presentations, the inability of the instructor to create a qualified communication (Erzen \& Ceylan, 2020) were determined to have negative effect on distance education process.

However, these aforementioned issues could become a topic for a further study. In a study examining the views of preservice Turkish teachers on distance education (Karakuş, Ucuzsatar, Karacaoğlu, Esendemir, \& Bayraktar, 2020), it was found that student motivation was very low in the courses in distance education process.

Gender and grade level had no effect on students' views related to teaching in distance education environments. It was understood that the views of male and female students towards teaching offered in distance education environments were similar. In addition, there was no difference between the views of first and second grade students. It was expected that positive experiences related to distance education would affect the views of students positively, and negative experiences would affect the views of students negatively. It was observed that the knowledge and experience of second-grade students related to distance education was not very effective in changing their views. The positive experiences that second-grade students could experience about distance education processes were also possible to contribute upon the positive transformation of their opinions on this subject. However, for this purpose, it was important to qualify the distance education processes and practices related to this process. Similarly, the qualifications of distance learning activities in the programs covered by the study could be discussed in a different study as topic. In a study by Kırali and Alci (2016), it was specified that students' perceptions of distance education did not differ significantly according to gender. In a study on the perception of distance education of preservice teacher (Başar, Arslan, Günsel, \& Akpınar, 2019), it was found that the perception of distance education of male students was higher than that of female students.

The type of school in which the student was enrolled affected the students' views on teaching offered in distance learning environments. The views of the students in the Health and Justice Group on the teaching offered in distance education environments were more positive than those of the students in the Vocational School and Hotel Management and Tourism Group. 
The program diversity of students in the Health and Justice Group was less than the program diversity of students in the Vocational School and Hotel Management and Tourism Group. The reason for this difference could be related to the nature of the courses in the associate degree programs in which the students were studying, or it could be due to the difference of the students' background related to distance education. However, the investigation of these issues could be carried out in a further study.

\section{References}

Başar, M., Arslan, S., Günsel, E., \& Akpinar, M. (2019). Öğretmen adaylarının uzaktan eğitim algısı [Pre-service teachers' perception of distance education]. Journal of Multidisciplinary Studies in Education, 3(2), 14-22.

Bayram, M., Peker, A. T., Aka, S. T., \& Vural, M. (2019). Üniversite öğrencilerinin uzaktan eğitim dersine karşı tutumlarının incelenmesi [Üniversite öğrencilerinin uzaktan eğitim dersine karşı tutumlarının incelenmesi]. Gaziantep Üniversitesi Spor Bilimleri Dergisi, 4(3), 330-345. https://doi.org/10.31680/gaunjss.586113

Bilgiç, H. G., \& Tüzün, H. (2015). Yükseköğretim kurumları web tabanlı uzaktan eğitim programlarında yaşanan sorunlar [Problems experienced in higher education institutions web-based distance education programs]. Açıöğretim Uygulamaları ve Araştırmaları Dergisi, 1(3), 26-50.

Birişçi, S. (2013). Video konferans tabanlı uzaktan eğitime ilişkin öğrenci tutumları ve görüşleri [Student attitudes and views on video conference-based distance education]. Ögrretim Teknolojileri ve Öğretmen Eğitimi Dergisi, 2(1), 24-40.

Cabı, E., \& Ersoy, H. (2017). Yükseköğretimde Uzaktan Eğitim Uygulamalarının İncelenmesi: Türkiye Örneği [Investigation of Distance Education in Higher Education Practice: The Case of Turkey]. Journal of Higher Education \& Science/Yüksekögretim ve Bilim Dergisi, 7(3). https://doi.org/10.5961/jhes.2017.219

Can, E. (2020). Coronavirüs (Covid-19) pandemisi ve pedagojik yansımaları: Türkiye'de açık ve uzaktan eğitim uygulamaları [Coronavirus (Covidien-19) pandemic and pedagogical implications: open and distance education applications in Turkey]. Açıöŏgretim Uygulamaları ve Araştırmaları Dergisi, 6(2), 11-53. Retrieved from https://dergipark.org.tr/tr/pub/auad/issue/55662/761354

Durak, G. (2017a). Uzaktan eğitimde destek hizmetlerine genel bakış: Sorunlar ve eğilimler [Overview of support services in distance education: issues and trends]. Açıköğretim Uygulamaları ve Araştırmaları Dergisi, 3(4), 160-173.

Durak, G. (2017b). Yükseköğretimde uzaktan eğitim sürecinde eski-yeni bir bölüm: BÖTE [An old-new section in the distance education process in higher education: CEIT]. Batı Anadolu Eğitim Bilimleri Dergisi, 11(2), 395-409.

Eken, Ö., Tosun, N., \& Tuzcu Eken, D. (2020). Covid-19 salgını ile acil ve zorunlu uzaktan eğitime geçiş: Genel bir değerlendirme [Urgent and compulsory move to distance education upon covid-19: A general evaluation]. Milli Ĕgitim, 49(1), 113-128. https://doi.org/10.37669/milliegitim.780722

Erzen, E., \& Ceylan, M. (2020). Covid-19 salgını ve uzaktan eğitim: Uygulamadaki sorunlar [The Covid-19 pandemic and distance education: ZProblems in practice]. EKEV Akademi Dergisi, 24(84), 229-262. https://doi.org/10.17753/Ekev1650

Falowo, R. O. (2007). Factors impeding implementation of web-based distance learning. AACE Journal, 15(3), 315-338.

Gökçe, A. T. (2008). Küreselleşme sürecinde uzaktan eğitim [Distance education in the globalization process]. Dicle Üniversitesi Ziya Gökalp Eğitim Fakültesi Dergisi, 11, 1-12.

Hara, N., \& Kling, R. (1999). Students' frustrations with a web-based distance education course. First Monday, 4(12). https://doi.org/10.5210/fm.v4i12.710

İbicioğlu, H., \& Antalyalı, Ö. L. (2005). Uzaktan eğitimin başarısında imkan algı motivasyon ve etkileşim faktörlerinin etkileri: Karşılaştırmalı bir uygulama [The effects of opportunity perception, motivation and interaction factors on the success of distance education: A comparative application]. Çukurova Üniversitesi Sosyal Bilimler Enstitüsü Dergisi, 14(2), 325-338.

İşman, A. (2008). Uzaktan Eğitim [Distance Education]. Pegem Akademi.

Karakuş, N., Ucuzsatar, N., Karacaoğlu, M. Ö., Esendemir, N., \& Bayraktar, D. (2020). Türkçe öğretmeni adaylarının uzaktan eğitime yönelik görüşleri [Turkish teacher candidates' views on distance education]. RumeliDE Dil ve Edebiyat Araştırmaları Dergisi, 19, 220-241. https://doi.org/10.29000/rumelide.752297 
Kaya, Z. (2002). Uzaktan Eğitim [Distance Education]. Ankara: PegemA Yayınc1lık.

Kırali, F. N., \& Alcı, B. (2016). Üniversite öğrencilerinin uzaktan eğitim algısına ilişkin görüşleri [University students' views on distance education perception]. İstanbul Aydin Üniversitesi Dergisi, 8(30), 55-83.

Kırmacı, Ö., \& Acar, S. (2018). Kampüs öğrencilerinin eşzamanlı uzaktan eğitimde karşılaştıkları sorunlar [Problems faced by campus students in simultaneous distance education]. Eğitimde Kuram ve Uygulama, 14(3), 276-291. https://doi.org/10.17244/eku.378138

Kürtüncü, M., \& Kurt, A. (2020). COVID-19 pandemisi döneminde hemşirelik öğrencilerinin uzaktan eğitim konusunda yaşadıkları sorunlar [Problems faced by nursing students in distance education during the COVID-19 pandemic]. Avrasya Sosyal ve Ekonomi Araştırmaları Dergisi, 7(5), 66-77.

Özgöl, M., Sarıkaya, İ., \& Özürk, M. (2017). Örgün eğitimde uzaktan eğitim uygulamalarına ilişkin öğrenci ve öğretim elemanı değerlendirmeleri [Student and instructor evaluations on distance education practices in formal education]. Yükseköğretim ve Bilim Dergisi, 7(2), 294-304.

Özkul, A. E., \& Girginer, N. (2001). Uzaktan eğitimde teknoloji ve etkinlik [Technology and activity in distance education]. Sakarya Üniversitesi Eğitim Fakültesi Dergisi, 3, 107-117.

Öztürk, H. (2020). Meslek yüksekokulu öğretim elemanlarının uzaktan eğitim sürecinde uyumlarının incelenmesi: Nitel bir araştırma [Examining the adaptation of vocational school lecturers in the distance education process: A qualitative research]. Mehmet Akif Ersoy Üniversitesi Eğitim Fakültesi Dergisi, 57, 74-97.

Özyürek, A., Begde, Z., Yavuz, N. F., \& Özkan, İ. (2016). Uzaktan eğitim uygulamasının öğrenci bakış açısına göre değerlendirilmesi [Evaluation of the distance education application from the perspective of the student]. Karabük Üniversitesi Sosyal Bilimler Enstitüsü Dergisi, 6(2), 595-605. https://doi.org/10.14230/joiss227

Wang, C., Cheng, Z., Yue, X.-G., \& McAleer, M. (2020). Risk Management of COVID-19 by universities in China. Journal of Risk and Financial Management, 13(2), 36. https://doi.org/10.3390/jrfm13020036

Yalın, H. İ. (2001). Öğretim Teknolojileri ve Materyal Tasarımı (5. Baskı) [Instructional Technologies and Material Design (5th ed.)]. Ankara: Nobel Yayınevi.

Yılmaz, H., \& Düğenci, M. (2010). Hizmet İçi Eğitime Farklı Bir Yaklaşım: E-Hizmet İçi Eğitim [A Different Approach to In-Service Training: E-In-Service Training]. Muğla Üniversitesi. Akademik Bilişsim Konferansı Bildirileri, 67-74.

\section{Copyrights}

Copyright for this article is retained by the author(s), with first publication rights granted to the journal.

This is an open-access article distributed under the terms and conditions of the Creative Commons Attribution license (http://creativecommons.org/licenses/by/4.0/). 